\title{
The Gift of a Sail in a Tale about King Haraldr harðráði Sigurðarson: Textile and Text
}

\author{
By William Sayers
}

\begin{abstract}
The exploration of the complexities of gift giving and reciprocity in often asymmetrical social relationships in the medieval North facilitates the resolution of textual difficulties in a tale from Morkinskinna about the gift of a sail to Haraldr harðráði Sigurðarson, assisted by recognition of the entertainment value attached to tvira $\partial i$ or 'ambivalence' in Old Norse poetry.
\end{abstract}

This essay explores the complexities of medieval Norse gift-giving and reciprocity as illustrated in Porvarðs páttrkrákunefs, which is incorporated in the saga of King Haraldr harðrádi Sigurðarson. ${ }^{1}$ In so doing the study attempts to resolve problems associated with a dialogue scene toward the close of the brief tale. This páttr is preserved only in the Morkinskinna manuscript of the kings' sagas. It introduces an Icelander, Porvarðr krákunef, who arrives at the Norwegian court in Niðaróss and offers King Haraldr a fine sail as a gift. ${ }^{2}$ The king declines the gift, having had a bad experience with a sail made in Iceland, and it is given instead to the king's brother-in-law and friend, Eysteinn orri Porbergsson, himself a chieftain (Msk 2000: 223, n. 1). Eysteinn shows his appreciation of the gift through a number of counter gifts. On a later occasion, when Haraldr and Eysteinn are out sailing, each on their own vessel, the king remarks on the rapid advance of his friend's ship and on the fine sail. Eysteinn observes that it is the very sail he had refused. Haraldr says that he has never seen a better sail and has obviously turned down a good thing. Eysteinn

1. On the páttr or short narrative as genre, see Rowe (2020), and Rowe and Harris (2005). Characteristic thematics, and placement in sagas and manuscript collections have received less scholarly atttention.

2. Morkinskinna [Msk] (2011: Ch. 45, 237-239). On the place of Morkinskinna in the Icelandic literary tradition, see Ármann Jakobsson (2014). 
replies: 'Viltu flensa í milli segla, herra?'(Msk 2011: 239 and n. 3). The king wonders aloud 'Why not?' and approaches the mast. Eysteinn then advises against any rash action, and invites the king to take the sail, if he so wishes, and to recognize the value of the gift offered him. The king does take the sail, which performs well in later racing, even though the king's ship was a large one. The sail was judged a miracle of fabrication.

One outstanding problem is philological: what does a word, and the expression in which it is used, mean? what is its affective valence? Scholars and translators, while conceding the difficulty of interpretation, appear to have taken Eysteinn's question, 'Viltu flensa í milli segla?' to mean 'Do you want to kiss between the sails,' as if this were an idiom reflecting the conciliation of a (potential) conflict, some variant on a 'kiss of peace' or 'kiss and make up', or a bargain sealer. The multiple interpretation(s) of his remark are, in reality, a good deal more complex. To elucidate his query in the context of gifting and relations with royalty, we return to the beginning of the tale, and, later, several programmatic statements by Eysteinn to Porvaldr on the subject of gifts, their real and symbolic values, the relative status of giver and recipient, and the institution of reciprocity. This approach draws on and complements recently published research in the larger issues of a) medieval gift-giving; b) court manners, or more exactly, the relations between the king's followers, including poets, and the king; c) skaldic poetry and the general appreciation of wit, at times of a scurrilous nature; d) nautical archaeology (in particular sailmaking); e) narratology; f) conceptions of just royal rule as reflected in specula regales; and g) the relations between Icelanders and the Norwegian throne in the thirteenth century.

porvarðr is introduced in the tale as a wealthy, well-travelled, and esteemed man. As a successful trader, he then recognizes the advantage in addressing the highest authority in a new social environment, in this case King Haraldr in Niðaróss. Did he know the king would be there? After unloading his ship and finding lodgings in the town, he goes to see the king at a time when Haraldr might be expected to be in the hall, at drink. porvardr expeditiously catches Haraldr just at the entry - literally and figuratively a liminal moment - and seizes the opportunity: 'Heill, herra! Hér er segl eitt niðri á skipinu er ek vilda at pér pægið’ (Msk 2011: 237; Greetings, sire, there is a sail down on my ship that I wish you to accept). There are no preliminaries. Concise and direct, the statement, not a request for a boon, puts the king on the spot. There is every likelihood that 
the sail is newly made but unused, and not hoisted on the trader's vessel, for which it would have been oversized, since by the tale's end we learn that it was not best suited to a king's warship but rather to a mediumlarge vessel. It is not explicitly identified as fabricated in Iceland but the narrative economy of the tale suggests that it was. The sail could have been of linen or, more likely, of wool. ${ }^{3}$ The former would have been more prestigious but conditions in Iceland were poor for the cultivation of flax (Magnús Már Lárússon 1965). The Icelander's gift is most likely to have been composed of wadmal, strips of woolen fabric produced on warpweighted upright looms, which seem to have occupied designated space in Icelandic farmhouses of the Middle Ages (Crowfoot 1937, Hoffman 1964, Petty 2014). If we take the wrecked warship (Skuldelev 2) recovered from Skuldelev Harbor, Denmark, as exemplary of a prestigious royal vessel - albeit one some 200 years earlier than the written tale we may take the hull of about 30 meters and beam of 2.6 meters as providing rowers' seats for 60 military men (Welcome on Board! 2007: 41). The quadratic sail, perhaps a bit taller than it was wide in the case of a royal vessel, would have been about 11 x 10 meters for an overall sail area of 110 square meters. In terms of material and labor, it is now judged that the fabrication of the sail and lime bast lines were as costly as the hull (Crumlin-Petersen et al. 2002: 326-327). A smaller warship than the king's, one on the scale of Hedeby 2, would have taken a 80 square meter sail (Crumlin-Pedersen et al. 1997: 188-190) and it has been estimated that the weaving that went into its production would have required two person-years, conceivably of slave or menial labor (Price 2020: 201-203, 386). Then would follow the sail-maker's intervention to assemble the parts, attach the braided pieces between lengths of fabric and bolt lines, dye the sail, and treat it with water-proofing agents, all the while seeking to shape the fabric for a uniform filling with wind. The isolated Icelanders would not have had the need or luxury to construct and outfit warships and the further incidents in the páttr strongly suggest that the sail was intended for use beyond the island.

3. Silken sails are mentioned in the romances, but are unlikely historically due to the exorbitant cost. Strips of silk may, however, have been used for decorative purposes; see Heide (2020). Cotton seems more realistic, but there is no evidence for extensive trade in cotton (and large bolts would have been required), and the archaeological record gives no indication of the spinning of cotton, which relies on a different technology from that of wool and linen. 
The weaving of the sail fabric would be exclusively the product of women's labor. Women and the sea is a complex and apparently fraught conceptual domain in early Norse culture and thereafter. Rán is goddess of the sea and it is she who receives the drowned. The mast partner was called kerling 'old woman', and the mast step into which the mast was fitted, klofi 'cleft' (Cleasby et al. 1956: s.vv., Heggstad et al. 1993: s.vv.). The presence of women on board was discouraged but men had to assume women's work at sea and when the ship was beached: hauling wood and water, cooking porridge, drying clothes, mending. The paradoxes are myriad (Jesch 2001).

King Haraldr declines the gift, with the explanation that he had previously had bad luck with a sail given him by an Icelander. In fact, the sail had split ('gekk ... sundr'). ${ }^{4}$ But the real reason may lie in the abruptness and circumstances of the offer, the latter often more complex than initially apparent, as will be seen in the following. Eysteinn urges prudence: 'Gakk til, 'herra,' segir hann, 'ok sé, ok kann vera at yðr sýnisk vel, ok pess er meiri ván at pér piggið pá hluti er óvirðiligri eru; pví mun hann pér ætlat hafa' (Msk, 2011: 237; Go and look at it, sire, and it may be that it will appeal to you, and it is more likely that you will accept things that are of less worth than that which he intended for you). This concept of relative value will recur throughout the tale. But the king is adamant and tells Eysteinn to keep his own counsel. Avoiding an awkward situation and saving face, Porvarðr then promptly offers the sail to the king's brother-in-law Eysteinn and it is accepted. Eysteinn invites the merchant to visit him but this does not occur until a chance meeting some time later when Porvarðr is well received and feted. His departure from Eysteinn's estate is delayed by successive days of poor sailing weather. This narrative device-sail and sailing suspended, as it were - gives Eysteinn the opportunity to discourse on gift-giving and compensation over the course of three days. For breaking off his merchant's trip to be Eysteinn's guest, Porvarðr is given a fine tunic, which is explicitly not juxtaposed with the gift of the sail. Porvaryr is recompensed for the sail the next day by the gift of a luxurious cloak. Just as the previous day's tunic could be worn in the hall, so the cloak has qualities in common with

4. Andersson (Msk 2000: 439-440, n. 3) suggests that Haraldr recognizes the merchant's Icelandic accent, but it is more likely that his harbormaster would have informed him of the arrival of a ship from Iceland. 
the sail. Eysteinn pointedly says that the cloak excels among cloaks as the fine sail among sails. Eysteinn is careful not to fault the king for declining a gift that he himself will accept. Haraldr's acceptance was simply not fated. The Icelandic text is worth close scrutiny at this point.

Eigi varð pat auðit at konungr pægi seglit at pér, en pess get ek, ef hann hefði pegit, at hann myndi pannig svá launa sem ek. En pó hefir pú nú ekki fyrir pat er nú gaf eigi konungr pér launin; en par má ek ekki at pví hafa, pó at ek sék ótignari en konungr. En fyr mismuna okkarrar tígnar skaltu piggja gullhring penna. (Msk 2011: 239)

It was not destined that the king should accept the sail from you but I think that, if he had accepted, he would have rewarded the gift in the way I have. Yet you now have nothing for the circumstance that it was not the king who gave you the recompense and there's aught to be done about my being less well-born than the king. And, because of this disparity in our estates, you shall have this gold ring.

A return favor or gift from Eysteinn cannot compete with similar acts by the king because of the difference in standing between the nobleman and the king. Thus, Eysteinn judges it fair that Porvarðr be given a supplementary gift in order to compensate for this difference. Eysteinn doesn't really need to lecture to Porvarðr; this is for the reader and, more importantly, lays the ground for what we have seen as Eysteinn's cryptic proposal to Haraldr. This idea of adjustment, bonus, or levelling in the transaction of reciprocal giving will figure in later events and comments. A fine artifact may have an absolute ('market') value; a value equivalent to that of another artifact; an experiential value, whether pleasure or profit; legendary or historical value based on prior ownership; and further less obvious values determined by the status of the giver, and even by any disparity in status between giver and recipient. In Njáls saga, for example, we find a silk cloak being refused as a bonus in a conciliatory legal settlement because of the impression of effeminacy it would convey, having originated with the beardless Njáll (Einar Ól. Sveinsson 1954: Ch. 123). Among the disparities that affect gift giving is the possibility of there being too great an economic distance between the giver and the gift (as well as between giver and recipient), e.g., a simple merchant in Icelandic goods and a sail fit for a royal ship. In the relationship between a 
non-aristocratic merchant and a king, the very fact of the latter accepting a gift could be viewed as a concession to the former and could initiate an alliance of sorts. This may have led to reluctance to accept. Receiving a gift is in the nature of a contract, which may put the recipient at some disadvantage. Negotiation may not always be possible and, of course, such possibility is lessened when the king is involved. Gifts might be passed along to subsequent recipients, each time crossing some kind of social boundary, as we eventually see here, the object increasing in value and interest through its accruing historical associations. There is always an unpredictable element, attitudes on the part of the would-be recipient, here illustrated by Haraldr's refusal but also by the days of unfavorable sailing weather - Eysteinn's perhaps weighted judgment in order to retain his guest - that lead to his three-part disquisition on gift-giving. All of these considerations, and many more, would also have been taken into account in the run-up to Porvarðr's original offer of the sail. There are similarities and possible affinities between gift-giving, and sacrifice and funeral practices, including grave goods, with even less predictable outcomes from the latter, but these cannot be explored in the present context. ${ }^{5}$

Eysteinn's last gift to Porvarðr is a gold arm ring, perhaps the most valuable of the three and that most reminiscent of gifts given by kings to retainers. After Eysteinn's three-part discourse on gift-giving, Porvarðr departs for a successful life back in Iceland and is so ushered out of the story. But his repute back in Iceland would also draw on the fact that his sail eventually made its way to the king's ship, as he had intended. Porvarðr's nickname is krákunef 'crow beak' and, while he seems to share the crow's astuteness, he displays none of its (or other Icelanders') loquacity and after his initial address of the king is credited with only a single reply to Eysteinn in direct speech. Parenthetically, we also note how little direct speech is accorded King Haraldr, thus leaving him as a figure in the narrative at some disadvantage vis-à-vis Eysteinn, who has the command of discourse. Eysteinn also has a byname, orri, or he-

5. On gift-giving, its role in alliances, and related, see Price (2020: 229-230, 232-233, 260-261), Viðar Pálsson (2020), Du Bois (1999: 19), and Jón Viðar Sigurðsson (2017). The complexity of this specific form of personal interaction is well illustrated by another tale, also found in Morkinskinna, Auðunar páttr vestfirska, in which this same King Haraldr asks outright for a gift of a polar bear, which the Icelander AuJunn dares to decline, since he hopes to give the bear to King Sveinn of Denmark. 
athcock, perhaps here alluding to his concern to maintain discreet, appropriate cover.

The tale then moves to the summer and the recreational sailing of Haraldr and Eysteinn. Impressed by the speed of the latter's advance, the king asks where he got the fine sail. Throughout, the sail is viewed instrumentally, functionally (as well as transactionally), almost retrospectively and at a distance, but not as a beautiful or finely made artifact, for which assessment we must wait for the end of the tale. 'Hér er nú seglit at pér neittuð, herra' (Msk 2011: 239; This is the sail you turned down, sire). With the negative verb neita 'refuse', Eysteinn's remark is rather pointed, since he might have employed greater indirection and observed that this was the sail that Haraldr had been offered months earlier. The king is not reluctant to own up to his hasty judgment and uses the same vocabulary: 'Ek sák aldri betri segl, ok hefi ek par góðu nítt' (I never saw a better sail and I have turned down a good thing). This repetition of the verb prepares for greater interplay of language. This is followed by Eysteinn's question with which this essay began: 'Viltu flensa í milli segla, herra?' This is a courtly, deferential question suggesting joint action. Haraldr does not try to answer in kind. The text continues: 'Konungr mælti ok brosti at: "Hví eigi?" segir hann; gekk upp siðan hjá siglunni' (The king said with a smile 'Why not?', he said; and he went up beside the mast). Two initial observations are in order. Firstly, the king's movement toward the mast from which the sail was suspended suggests that some further physical action may be expected, although not necessarily so. Secondly, translator Theodore Andersson, with regard to Eysteinn's proposal, astutely suggests that '[s]ince Haraldr laughs, we may suspect some sexual innuendo' (Msk 2000: 440, n. 5; see further below on the king's taste for the scurrilous). This prompts the punning translation of Eysteinn's remark as 'Do you want to kiss between the sheets, sire?' (sheets referencing both ship's lines attached to the corners of a sail, and bedclothes). Such a rhetorical tactic on Eysteinn's part could have been intended to dispel the tension created by Haraldr's annoyance at having missed out on a good thing. In 1997 George Clark unpacked Eysteinn's offer as 'Do you want to trade sails and throw a kiss into the bargain, my lord?' (Clark 1997: 398). In the modern edition of Morkinskinna, published in 2011 and thus ten years after Andersson's interpretation, the editors assume that Eysteinn is explicitly offering his sail to Haraldr but that some compensatory gift must also be considered. Yet in their gloss on Eyste- 
inn's comment they consider the identification of flensa as 'to kiss' only probable ('likl.') and go on to make the Old Norse preposition milli do double service: 'Viltu piggja kjass i milligjöf milli seglanna?' (Msk 2011: 239, n. 3; Will you accept a kiss [or embrace] as a mediating gift in the matter of the sails?). This interpretation neatly recalls Eysteinn's exposition to Porvarðr on social imparity and the possibility of a need for compensatory action (a top-up) in the matter of gifts. Yet none of these interpretations, seen in the light of Haraldr's smile and move toward the mast, would justify Eysteinn's next warning remark: 'Gør pik eigi at undri ok haf segl hvárt er pú vill, ok er vel at pú vitir hverju pú níttir' (Msk 2011: 239; Don't make a spectacle of yourself and take whichever sail you will, and it's good that you know what you refuse). In Eysteinn's view, the king could be at some risk of shaming himself by a rash action, which could take the form of damage to the sail(s) or to his reputation. The second part of his remark may be lightly sarcastic, with its air of a gnomic commonplace: 'Always know what it is that you are turning down.'

The problematic word flensa will now be considered in a wider context, one that will also provide evidence for Andersson's surmise that Eysteinn has used, or Haraldr perceived, a double entendre in the hopedfor resolution of the matter of the sail. The anecdote with the gift of a sail is preserved in the Morkinskinna manuscript and is followed by King Haraldr's wars with King Sveinn of Denmark and dealings with the sometime jarl Hákon Ívarsson, an account with some motifs in common with the present tale (Msk 2011: 240-269). This account, in turn, is followed by Sneglu-Halla páttr, one of the so-called skalds' pattir. ${ }^{7}$ This short narrative is also found in Flateyjarbók in more ample form. ${ }^{8}$ Towards the conclusion of the latter recension, the Icelandic poet Sneglu-Halli is involved in trickster adventures and scurrilous verse exchanges on a more heightened scale than early in the tale, and these are absent from the Morkinskinna recension. Among these episodes King Haraldr encounters

6. Goeres (2020: 233), employs the term 'quasi-gnomic' for this trope often met in the intercalary clauses of skaldic verse and in fraught dialogue in the sagas of Icelanders.

7. Msk (2011: 270-284); the tale has several themes and motifs in common with the sail episode but also addresses weightier questions of royal rule, in particular the relationship between the king and his men, and thus opens a window on Norse conceptions of prince literature.

8. On Flateyjarbók, see Louis-Jensen (1969) and Rowe (2006); on Sneglu-Halla páttr, Danielsson (1993), Turco (2015), and Sayers (forthcoming). 
Halli in a street and notices his attention to the fine axe that the king is bearing. He asks Halli whether he would be willing to be sodomized in return for the axe. Halli had earlier engaged in dangerous dialogue with the king when their ships met at Niðaróss and now his reply is in the same scurrilous register as his early retort to the royal interrogator. ${ }^{9} \mathrm{He}$ now replies: 'en várkunn pykki mér yðr, at pér vilið svá selja sem pér keyptuð' (Sneglu-Halla páttr [SHp] 1956: 294; It seems understandable to me that you should wish to sell at the same price as you bought; cf. Finlay 2001). The king appreciates the cleverness and lets the sexual innuendo pass. He received the axe as a gift and so Halli shall have it in the same mode. But after this exercise in axiology (to stay with the tale's word play), Queen Póra (Eysteinn's sister) thinks it scandalous that the king should allow himself to be talked to in that fashion. Haraldr states that he alone will determine what is permissible: 'vil ek eigi snúa orðum Halla til ins verra, peim er tviræði eru' (SHP 1956: 294; 'I don't wish to turn to the worse words from Halli that are tvíreði). Tvire $i$ has often been rendered 'ambiguous' (SHP 1997 [Clark]: 356, Turco 2015:, 210, and Abram 2018) but we may prefer 'ambivalent', it being not so much a question of obscurity as of two known valences, only one of which is unacceptable in public or in the presence of one's betters. ${ }^{10}$ Haraldr charges Halli to compose an ambivalent statement ('mæla nokkur tviræðiorð') about the queen. One reading is that Póra is the most suitable sexual partner for the king but is accompanied by explicit detail on the act of penetration that enrages the queen, who calls the stanza slanderous.
pú est markligust miklu. munar stórum pat, Póra, flenna upp at enni allt leðr Haralds reðri. ${ }^{11}$

9. Meulengracht-Sørensen (1983) remains the fundamental study in this important sphere of social values and interaction.

10. It should be noted that Snorri Sturluson in his Skáldskaparmál treats of ambivalence on the level of lexis - puns and other word play characterized as ofljóst 'too clear' or tvikent 'ambiguous' (Snorri Sturluson 1998: 109) - and was certainly familiar with the entertaining practice of treating base subjects in high register poetic form but he does not address ambiguity on the level of the utterance or short poetic form as here.

11. SHp (1956: 294). Gade translates, with some curious notions of anatomy: 'Póra, you are by far the most deserving - there is a great difference - to pull all the skin of $\mathrm{Ha}$ raldr's prick up from the head' (SHp 2009: st. 10). 
George Clark translates:

You are the most fitting by far,

by a long mark, Thora,

to roll down from a rising crag

all the foreskin on Harald's prick. (SHP 1997: 356)

But what is ambiguous in this reading? For Halli to have met Haraldr's criteria for tvíredi, an innocuous reading must also be available. ${ }^{12}$ The verb flenna means 'to uncover, peel back'; enni is the forehead, by extension a 'mountain crag'. Leðr is more narrowly 'leather', not 'skin'. Reðri does mean the 'genitals', especially of animals. But on the analogy of other fraught sexual vocabulary like ergi and ragr that appear in metathesized alloforms, reðri might be imagined as a reconfiguration of erði, which meant 'balk, beam'. With these alternative significations, the couplet could also be translated as 'to peel back all the leather from Haraldr's forehead to the nape of his neck (beam).' The queen is being identified by Halli as the person most fitted for the intimate act of removing the leather cap or liner worn by Haraldr under his helmet - or so we may speculate on the subtext.

Haraldr lets this pass as illustrating his point of the offensive being in the ear of the hearer. More in the same vein follows. The essential points for present purposes are two: the instance of the verb flenna in an episodic text associated with King Haraldr (although the story of the axe and commissioned verses is not found in Morkinskinna) and the more important concept of tvira $i$. This is not the context for an extensive discussion of poetic ambivalence. Indeed, this double-bottomedness is intrinsic to skaldic poetics, for what is a kenning but the novel juxtaposition of two disparate entities to designate an otherwise unnamed third, if the hearer is at home with the conventions and has some of the sense of the poet's verbal play. Language lacks absolute discreteness and improvisation with existing lexis must make do. Tvirrefi with its suggestion of hig-

12. On the cultural background necessary for such readings, see Lindow (1975). On Haraldr's verse presentation of his own several skills, see his stanza in Gade (2009: 4) and further Nedrelid (2005). These include verse composition and the interpretation of its complexities, making him well equipped to understand Eysteinn's polyvalent proposal. For the view of contemporary poets and historians, see Orning (2020: 116). 
her and lower registers recalls the ideas of social imparity in gift-giving that are otherwise explored in the tale.

Poetic ambivalence is associated in the tradition with Haraldr and his taste for base wit. Thus Andersson's suggestion that he recognizes it in Eysteinn's remark is fully plausible. Flensa and flenna seem near doublets (de Vries 1959, s.v. flensa, Cleasby et al. 1956: s.vv., Heggstad et al. 1993: $s . v v$.). The former, as noted, is often understood as a familiar or vulgar term for 'to kiss' or 'to lick' but the underlying image is of the parting of conjoined surfaces, the opening of the lips, which may lead to further action. ${ }^{13}$ The latter form, flenna, is also used of the peeling back of joined or superposed surfaces, as seen in the incident with Póra. Given the genital imagery associated with the ship's mast-step and keelson, I propose that Eysteinn's superficially reconciliatory offer also carries a reference to the parting of a woman's external genitalia or labia majora, without, however, being in any way insulting to the king. Even $i$ milli turns out to be a polyvalent term, and thus appropriate to a context of tviredi. As a simple adverb it means 'in the middle' or, as preposition, 'between', but can be used figuratively in the sense of 'in the matter of'. Modern Icelandic, as noted above, uses this element in the compound milligjöf, the supplementary payment in a transaction when the two items or lots were of unequal value (Sverrir Hólmarsson et al. 1989: s.v.), a notion with deep historical roots and just what was realized between Eysteinn and Porvarðr, and perhaps proposed here between Haraldr and Eysteinn.

From the perspective of tvira $\partial i$, as intended by the speaker, not as necessarily perceived by the hearer, Eysteinn's proposal(s) may then be recast in three forms: familiar, neutral, and vulgar. The first is the commonly understood 'Shall we kiss to settle the sail business?' The second, an intermediary path of action that evokes a more technical valence of the verb flensa, is: 'Shall we peel apart the matter of sails?' that is, differentiate and establish the relative merits of each of the sails that have been situationally conjoined the sailing race (which would not necessarily lead to action or a gift) and deal with the fact that the better sail, intended for Haraldr, has gone to Eysteinn. Third and last is: 'Shall we split the sail business up the middle (as one might a woman)?' Haraldr has to be

13. Flensa in the sense of cutting blubber off a whale is not attested in the Old NorseIcelandic corpus, yet its early use seems more reasonable than the assumption of a later loan from Dutch; see de Vries 1959: 130, s.v. flensa. 
managed and his known tastes taken into account. These interpretative options would evoke very different emotional reactions, as determined by the registers in which they are situated by the auditor (Sif Rikhardsdóttir 2020: 41-42). To stand back, momentarily, from the incident, the term used of a short narrative or section of a law code is páttr, literally a strand of rope or a hank of unspun wool. Eysteinn's proposal is then in the nature of a triple-ply length of yarn. His question must be 'unplyed' into its constituent significations. In such a deconstruction of the social situation and of Eysteinn's remark, the placement of the incident or 'strand' in the larger history of Haraldr must also be taken into account.

An amical transaction in a conventional register or an impartial assessment are contrasted with a more forceful resolution on a lower register in the imagery of sexuality, perhaps even violation. It recalls the fate of Haraldr's purported earlier Icelandic sail, splitting asunder. For the king to make a decision will, itself, require an act of flenna/flensa, distinguishing three options, two overt and one covert, in the question, as well as possibly making a judgmental distinction between the two sails. Haraldr's smile and move toward the mast suggests that he is acknowledging the subtext, although this is not necessarily a commitment to action, only a hint, yet one that establishes his recognition of one of the 'available' readings. Yet the third option would provide Haraldr with no bonus, save the emotional satisfaction of a willful, autocratic action. Or the action proposed here may entail stripping both sails from their mast, a double separation. The first alternative, an 'overt' proposal, could take a simple form - the two men embrace-but still have a variety of subjective or shared meanings, if we bear in mind Eysteinn's exposition on giftgiving. If it is Eysteinn who might be compensated for the surrender of the sail, his bonus gift would be a kiss from the king. If it is the king who should be compensated, the kiss would offset his inconvenience at not having had the use of the sail for the past months. Not that this is Eysteinn's fault, of course. Since the kiss is working in both directions, both interpretations - and perhaps still others-are valid.

In this fluid situation, Eysteinn then intervenes to preclude any hasty action on the king's part-cutting down a sail (although we do not know on whose ship the men stand), cutting a sail in two-and thus pulls back from his venture into the lower register. He unconditionally cedes the sail to the king but not, as we have seen, without an ironic coda (with a hint of the tone of a King's Mirror or speculum regale) which, with its ap- 
peal to common sense, also serves to return to a socially acceptable level of discourse: 'Gør pik eigi at undri ok haf segl hvárt et pú vill, ok er vel at pú vitir hverju pú níttir' (Don't make a spectacle of yourself and take whichever sail you will, and it's good that you know what you refuse). Eysteinn's hope is to move on.

The anecdote wraps up quickly with a neat recall of the theme of imparity in ostensibly reciprocal relations. 'Konungr pakkaði honum ok hafði petta segl yfir sínu skipi, ok stózk pat eigi pessu konungsskipinu i kappsiglingum, pví at skip var mikit, en pó pótti pat vera in mesta gørsimi' (The king thanked him and had that sail raised on his ship. It was not adequate for that royal vessel in competitive sailing, because the ship was large, yet it was judged to be a very valuable artifact). Thus, popular opinion triumphs and the true match was between Porvarðr's sail and Eysteinn's ship all along. Yet in retrospect we see that the very quality of the sail meant that it had to be first offered to the king.

The anecdote of the gift of a sail is immediately followed in Morkinskinna with a return to the political life of the king and to the account of his dealings with Hákon Ívarsson, who has supported Haraldr in his military undertakings against King Sveinn of Denmark but was not initially a royal retainer. Several motifs from the sail story are carried over or, inversely, it is the story of Hákon's dealings with the king that has occasioned the placement of the sail anecdote in Morkinskinna, and possibly that of Sneglu-Halla páttr, which immediately follows the account of $\mathrm{Ha}-$ raldr and Hákon. For his support Hákon is promised a bride, Ragnhildr, the daughter of the late King Magnus of Norway. Because of the imparity in social standing, forcefully reiterated by the bride-to-be, Hákon is to be awarded a jarldom, what might be considered the bonus in the marital transaction. Getting Haraldr to realize this promise makes up the substance of the account. The reverse of a gift, the loss of a valued battle standard, and the need to recover it to placate its former owner, Ragnhildr, is also a key part of the story. Haraldr predicts that Ragnhildr will deny Hákon access to the marital bed (the 'splitting' of the conjugal pair) if he does not recover the banner. Just before the recapture of the standard, the text offers two appreciations of Hákon's career, separating the historical strands, as it were (Msk 2011: 266-267). At this point in the saga of Haraldr's career, there is also another brief exemplification of how impudent and imprudent words are to be received. Haraldr spares a captive leader who castigates him, despite the threat of death, not, ap- 
parently, because of his wit but because of his bravery - the extra something that not all bring to verbal contention (Msk 2011: 251). At this point in the saga there are related incidents with well-born men in disguise or with an apparent disability (a man fishing, a blind man), who are nonetheless expert in extemporaneous versifying.

Although he is called Haraldr's favorite courtier and, indeed, was slated to marry his daughter, Eysteinn orri is mentioned only one further time in the history of the king and this at the Battle of Stamford Bridge in 1066, when-ironically-he arrives too late from the beached fleet he had been guarding to assist the by-then fallen king, and in a desperate coda to the battle, he and his troops are all killed, as was most of Haraldr's host. The saga tracks one survivor, Styrkárr stallari, the royal marshal who, coatless but with a sword, meets an Englishman in a coat. The Englishman refuses to sell the coat and says he would like to kill Styrkárr because he is a Norwegian but lacks a sword. The marshal observes that he, however, does have a sword, then cuts the man's head off and takes the coat (Msk 2011: 322). Thus ends the string of transactions at and about Haraldr's court, with the failed bargain at the end of the king's reign in grim counterpoint to Eysteinn's gift of a cloak for a sail and further gift of the sail to secure the king's favor. Or is this just narrative coincidence that nonetheless raises the question of textual cross-referencing - tighter weaving of incident and plot-and resonance in the collective memory of listeners and readers of a variety of incident from the rich life of the king? As it well recognized, memory is central to pre-literate collective life but it is rarely the subject of illuminating comment by the principals (Glauser et al. 2018).

The complexity of gift-giving in the kings' sagas and elsewhere seems matched by that of the accompanying dialogue. Literalist readings of the latter would restrict themselves to comments on lexical choices with reference to mainstream use and well respected historical dictionaries. Readings that recognize the Norse taste for word-play, allusion, the occasional archaism, intellectual puzzles (otherwise so evident in kennings) will pursue sub- and parallel texts, where more conservative readers may be reluctant to recognize them. Intentional obscurantism may make the task of interpretation more problematic. The present essay has taken some interpretive license in the explanation of the key vocabulary. A single line of dialogue, cited by scholars as a textual difficulty and perhaps originally intended to be ambivalent, turns out -like the two dimensions 
of gift-giving - to be vital to the appreciation of the whole tale. Tviredi or ambivalence calls for discrimination, neatly caught in the fundamental, and proposed but still speculative figurative meanings of the verbs flensa and flenna, particularly in a shared sense of 'to peel apart'.

The image of King Haraldr in the anecdote is consistent with that in his saga as a whole: interest in praise poetry, scurrilous wit, and other incongruities (germane to ambivalence and shifts of register), extemporaneous versifying under royal command, word puzzles and intellectual challenges. Competitive sailing is matched by verse-capping at court, the element of challenge present even in artistic creation. Eysteinn appears to have handled the situation generated by the racing ships by appealing to the king's known tastes, which generally puts him in a tolerant, generous mood. According to the protocols of transaction in asymmetrical relationships, simple speech need not be the prime medium for negotiation but can be an expedient invoked under trying circumstances, e.g., how does one rectify or ease a royal mistake or precipitous judgment? In the transaction of interactive speech, Haraldr will tolerate a criticism or insult, if it has the bonus value of wit. In terms of royal image and propaganda, the king may pre-emptively choose the base register in order to forestall real censure by receiving insult as play. The relationship between the king, and his courtiers and supplicants is always one of imparity. Relative social rank is then of great importance; a dynamic is always at work and equilibrium rare. Gift-giving and the dependent fate of gifts given in the early Northern world is complex and has parallels in numerous other world cultures. To be of value, gifts must occur within established social hierarchies and conventions. The supplementary or return gift is often also an option or a necessity. In this tale the gift has the same propulsive properties as the wind-driven sail itself, as does, elsewhere in early Norse culture, the "inspired" poet on the social fabric.

The greater context of reciprocity in the medieval Norse world evident in the páttr includes Norwegian shipments of natural resources to Iceland, of Icelandic poets, courtiers, and fighting men to Norway, or, in particular, timber for ship-building from Norway, fine sails from Iceland. It is tempting to see in the literary expression of the relationship between Norwegian kings and Icelandic poets and merchants the greater geopolitical situation in the troubled thirteenth century of Norwegian hegemonic ambition and threatened Icelandic independence. The brief narrative of the gift of a sail is a modest but self-contained and illumina- 


\section{William Sayers}

ting tale. Nonetheless, it prompts a number of further questions of interest to modern readers and scholars, not least those of literary objectives in the select placement of pattir in royal biographies and collections of other sagas, and of their relevance to the greater surrounding thematics of royal rule, and personal, political, and national history.

\section{Sources}

Björn K. Pórólfsson and Guðni Jónsson, eds. 1943. Auðunar páttr vestfirska. In Vestfirðinga sögur. Reykjavík: Hið íslenzka fornritafélag. 359-368.

Clark, George, trans. 1997. The Tale of Thorvard Crow's-Beak. In Viðar Hreinsson, ed. The Complete Sagas of Icelanders. Reykjavík: Leifur Eiriksson Pub., I. 397-399.

Einarr Ól. Sveinsson, ed. 1954. Brennu-Njáls saga. Reykjavík: Hið íslenzka fornritafélag.

Gade, Kari Ellen, ed. 2009. Haraldr harðráði Sigurðarson, Gamanvísur. In Gade, Kari Ellen, ed. Poetry from the Kings' Sagas 2: From c. 1035 to c. 1300. Poetry of the Scandinavian Middle Ages 2. Turnhout: Brepols, 9-40.

Msk $2000=$ Andersson, Theodore M., and Kari Ellen Gade, trans. 2000. Sneglu-Halla páttr. In Morkinskinna: The Earliest Icelandic Chronicle of the Norwegian Kings (1030-1157). Ithaca, NY: Cornell University Press, 243-252.

Msk 2011 = Ármann Jakobsson and Pórður Ingi Guðjónsson, eds. 2011. Morkinkinna. 2 vols. Reykjavík: Hið íslenzka fornritafélag.

SHp 1956 = Jónas Kristjánsson, ed. 1956. Sneglu-Halla páttr. In Eyfirdinga segur. Reykjavík: Hið íslenzka fornritafélag, 1956, 263-295.

SHp 1997 = Clark, George, trans. The Tale of Sarcastic Halli. In The Complete Sagas of Icelanders, ed. Viðar Hreinsson, Reykjavík: Leifur Eiriksson Pub., 1997, I, 342-357.

SHp 2009 = Gade, Kari Ellen, ed. 2009. Sneglu-Halli, Lausavísur. In

Gade, Kari Ellen, ed., Poetry from the Kings' Sagas 2: From c. 1035 to c. 1300. Turnhout: Brepols, 325-326.

SHp 2011 = Ármann Jakobsson and Pórður Ingi Guðjónsson, eds. 2011. Sneglu-Halla páttr. In Morkinskinna. 2 vols. Reykjavík: Hið íslenzka fornritafélag, 237-239. 
Sigurður Nordal, ed. 1936. Egils saga Skallagrímssonar. Reykjavík: Hið íslenzka fornritafélag.

Snorri Sturluson 1998. Skáldskaparmál. Anthony Faulkes, ed. London: Viking Society for Northern Research.

Secondary Works

Abram, Christopher. 2018. Trolling in Old Norse: Ambiguity and Excitement in Sneglu-Halla páttr. In Baragona, Stephen Alan, and Elizabeth Louise Rambo, eds. Words that Tear the Flesh: Essays on Sarcasm in Medieval and Early Modern Literature and Cultures. Berlin and Boston: de Gruyter, 2018, 41-62.

Ármann Jakobsson. 2014. A Sense of Belonging: Morkinskinna and Icelandic Identity, c. 1220. Odense: University Press of Southern Denmark.

Cleasby, Richard, Guðbrandur Vigfússon, and William A. Craigie, eds. 1957. An Icelandic-English Dictionary. $2^{\text {nd }}$ ed. Oxford: Clarendon.

Crowfoot, Grace. 1937. On the Warp-Weighted Loom. The Annual of the British School at Athens 37, 36-47.

Crumlin-Pedersen, Ole, et al. 1997. Viking-Age Ships and Shipbuilding in Hedeby/Haithabua and Schleswig. Roskilde: The Viking Ship $\mathrm{Mu}-$ seum.

Crumlin-Pedersen, Ole, et al. 2002. The Skuldelev Ships I: Topography, Archaeology, History, Conservation and Display. Roskilde: The Viking Ship Museum.

Danielsson, Tommy. 1993. Sneglu-Halla páttr. In Philip Pulsiano and Kirsten Wolf, eds. Medieval Scandinavia: An Encyclopedia. New York: Garland, 599-600.

Du Bois, Thomas. 1999. Nordic Religions in the Viking Age. Philadelphia: University of Pennsylvania Press.

Finlay, Alison. 2001. Monstrous Allegations: An Exchange of ýki in Bjarnar saga Hitdoelakappa. Alvissmál: Forschungen zur Mittelalterlichen Kultur Skandinaviens 10, 21-44.

Glauser, Jürg, Pernille Hermann, and Steven A. Mitchell, eds. 2018. Handbook of Pre-Modern Memory Studies. 2 vols. Berlin: de Gruyter. Goeres, Erin Michelle. 202O. Skaldic Poetry-A Case Study: The Poetry of Torf-Einarr Rognvaldsson of Orkney. In Massimiliano Bampi, Carolyne Larrington, and Síf Rikhardsdóttir, eds. A Critical Companion 
to Old Norse Literary Genre. Woodbridge: Boydell and Brewer, 229244.

Heide, Eldar. 2020. Dekorerte segl i vikingtida og mellomaldere. https://eldar-heide.net/onewebmedia/PDFer/Skipsartiklar/ Heide\%2O2O12,\%2ODekorerte\%2Osegl\%2Oi\%2Ovikingtida\%2Oog\%2 omellomalderen.pdf.

Heggstad, Leiv, Finn Hødnebø, and Erik Simensen, eds. 1993. Norrøn ordbok. Oslo: Det Norske Samlaget.

Hoffman, Marta. 1964. The Warp-Weighted Loom: Studies in the History and Technology of an Ancient Implement. Oslo: Scandinavian University Press.

Jesch, Judith. 2001. Women and Ships in the Viking World. Northern Studies 36, 49-68.

Jón Viðar Sigurðsson. 2017. Viking Fiendship: The Social Bond in Iceland and Norway, c. 900-1300. Ithaca, N.Y.: Cornell University Press.

Lindow, John. 1975. Riddles, Kennings, and the Complexity of Skaldic Poetry. Scandinavian Studies 47, 311-27.

Louis-Jensen, Jonna. 1969. Den yngre del af Flateyjarbók. In Jakob Benediktsson, Jón Samsonarson, Óláfur Halldórsson, and Stefán Karlsson, eds. Afmelisrit Jóns Helgassonar 30. Júni 1969. Reykjavík: Heimskringla, 235-250.

Magnús Már Lárússon. 1965. Lin. Kulturbistoriskt lexikon för nordisk medeltid, vol. 10, 582. Malmö: Allhems. 10, 582.

Meulengracht-Sørensen, Preben. 1983. The Unmanly Man: Concepts of sexual defamation in early northern society. Odense: Odense University Press.

Nedrelid, Gudlaug. 2005. Wie viele Künste konnte könig Harald? NOWELE 46-47, 193-210.

Orning, Hans Jacob. 2020. The Body Politic. In Massimiliano Bampi, Carolyne Larrington, and Síf Rikhardsdóttir, eds. A Critical Companion to Old Norse Literary Genre. Woodbridge: C. S. Brewer, 115-125. Petty, Christina. 2014. Warp Weighted Looms: Then and Now: AngloSaxon and Viking Archaeological Evidence and Modern Practitioners. Manchester: University of Manchester.

Price, Neil. 2020. Children of Ash and Elm: A History of the Vikings. New York: Basic Books. 
Rowe, Elizabeth Ashman. 2006. The Development of Flateyjarbók: Iceland and the Dynastic Crisis of 1389 . Odense: University Press of Southern Denmark.

Rowe, Elizabeth Ashman. 2020. Pettir - A Case Study: Stjörnu-Odda draumr. In Massimiliano Bampi, Carolyne Larrington, and Síf Rikhardsdóttir, eds. A Critical Companion to Old Norse Literary Genre. Woodbridge: Boydell and Brewer, 258-270.

Rowe, Elizabeth Ashman, and Joseph Harris. 2005. Short Prose Narrative (páttr). In McTurk, Rory, ed. A Companion to Old Norse-Icelandic Literature and Culture. Maldon, MA: Blackwell, 462-478.

Sayers, William. 2020. Guilt, Grief, Grievance, and the Encrypted Name in Egill Skallagrímsson's Sonatorrek. Scandinavian Studies 92.2, 229246.

Sayers, William. Forthcoming. Command Performance: Coercion, Wit, and Censure in Sneglu-Halla páttr. Mediaevistik.

Sif Rikhardsdóttir. 2020. Hybridity. In Massimiliano Bampi, Carolyne Larrington, and Síf Rikhardsdóttir, eds. A Critical Companion to Old Norse Literary Genre. Woodbridge: C. S. Brewer, 31-45.

Sverrir Hólmarsson, Christopher Sanders, and John Tucker, eds. 1989. Ílenzk-ensk orðabók. Reykjavík: Iðunn.

Turco, Jeffrey. 2015. Loki, Sneglu-Halla páttr, and the Case for a Skaldic Prosaics. In Jeffrey Turco, ed. New Norse Studies: Essays on the Literature and Culture of Medieval Scandinavia. Ithaca, NY: Cornell University Press, 185-241.

Viðar Pálsson. 2020. Language of Power: Feasting and Gift-Giving in Medieval Iceland and its Sagas. Islandica 6o. Ithaca, NY: Cornell University Press.

de Vries, Jan. 1959. Altnordisches etymologisches Wörterbuch. 2nd ed. Leiden: Brill.

Welcome on Board! The Sea Stallion from Glendalough: A Viking Ship Recreated. 2007. Copenhagen: The Viking Ship Museum.

\section{Sammandrag}

Lösningen av textkritiska svårigheter i en berättelse från Morkinskinna om ett segel som skänks Haraldr harðráði Sigurðarson inleds med en undersökning av det underhållningsvärde som erbjuds av tvíræði eller tve- 


\section{William Sayers}

tydighet i fornnordisk diktning och följes av en utredning av det komplexa hänsynstagande som åtföljer gåvor och deras mottagande i asymmetriska socialförhållenden som präglar den medeltida Norden.

William Sayers

701 Rivers Run

Rochester, NY 14623

USA

ws36@cornell.edu 